\title{
Creativity, Culture and Trade Union Density in Developed Countries
}

\author{
Basu Sharma \\ University of New Brunswick, Fredericton, Canada
}

\author{
Azmat Gani \\ University of Bahrain, Bahrain
}

\begin{abstract}
This paper presents the findings of our new research on the influence of creativity and culture on trade union density for a sample of 22 developed market economies. The findings indicated that an increasing level of creativity negatively influences trade union density, whereas dimensions of national culture especially individualism have a strong positive effect on the union density. Economy variables, such as rate of economic growth and unemployment rates have a strong positive effect on the union density. Since developed economies are becoming increasingly knowledge-based, there is less hope for a reversal in the fate of trade unions as the foundation for such an economy is creativity.
\end{abstract}

Keywords: creativity, culture, business cycle, trade union density

\section{Introduction}

Union influence on the labor market outcomes, such as wages, benefits, employment and working conditions in particular and on the economy and society in general can be gauged by looking at trade union density (Rose \& Chaison, 1966; Johnson, 2002). However, trade union density has been falling in many developed countries (Visser, 2002). The decline started over three decades ago, and it seems that it has not reached a turning point yet. Since this phenomenon has important implications for distribution of power between management and employees at the workplace and for overall welfare at the societal level, trade union leaders as well as scholars and policy makers are concerned about finding ways to stop it.

Theories of union growth and decline have identified some key variables that influence union density, which include wages, prices, employment and socio-political climate. However, given the profound structural changes in the economies and societies over the years, it seems appropriate to look for variables beyond what the mainstream literature suggests. The purpose of this paper is to do so in a modest way by incorporating creativity and culture variables.

\section{Theoretical Considerations}

There is a rich body of theoretical and empirical literature on the determinants of trade union membership growth. Since union density is dependent on growth to a large extent, this literature should explain the rise and fall of trade union density as well. The author summarized the main arguments of this rich body of literature next.

Basu Sharma, Ph.D., professor, Faculty of Business Administration, University of New Brunswick.

Azmat Gani, Ph.D., College of Business Administration, University of Bahrain. 
Even though there is a long history of scholarly research on trade union membership growth and decline, it is the B-E (Bain and Elsheikh) model that has guided much of the recent empirical research (Bain \& Elsheikh, 1976; Elsheikh \& Bain, 1978; Fiorito, 1982; Kumar \& Dow, 1986; Sharma, 1989; Bhattacherjee \& Chaudhuri, 1994; Vandaele, 2005). The B-E model has a strong theoretical underpinning as it is based on the business cycle theory. It uses the rate of change of trade union membership as the dependent variable and the rate of change in money wages, the rate of change of prices, the level of unionization and the level or the rate of change of unemployment as the independent variables.

One of the alternatives to the B-E model of trade union membership growth is the social custom theory (Booth, 1985). According to this theory, reputation of a group determines whether new members will be joining or shunning it. If the beliefs and actions of the group are positively perceived by members, they will join the group. Thus, it is the reputation of the unions that attracts or detracts new members. However, a minimum level of unionism is required for the reputation effect to take place (Booth \& Chatterji, 1995). Past union density can be used as a proxy to determine the effect of the reputation effect. Not withstanding the important influence of this literature, our main objective is to focus on culture and creativity factors. Hence, we used only two macroeconomic variables namely unemployment rate and per capita rate of growth of GDP (Gross Domestic Product). Since employers may be able to easily oppose trade unions and unemployed union members may drop out of unions in times of high unemployment rate, it should have a negative effect on trade union density. This may be referred to as the composition effect-the composition of the labour force in terms of employed and unemployed workers in the labour market. Growth of GDP is a proxy for price increases and money wage increases. Workers may give credit to unions for increased money wages and consider unions as protecting workers from price increases. The former is called the credit effect and the latter is the threat effect. Due to both effects, the rate of growth of GDP should have a positive effect on the trade union density.

While quite a bit of variations in unions growth or densities are explained by the models that use these traditional variables, there is an opportunity for introducing new dimensions to this literature. Given increasing globalization and changing structure of the working people, it seems reasonable to incorporate variables related to these two phenomena into models of union density. This research uses measures of creativity reflected in the changing structure of the working people and dimensions of national culture to explain variations in union density across nations.

According to Florida (2002), creative community are characterized by three Ts-technology, talent and tolerance. He has created an index of creativity for a number of countries based on these three attributes. Since one of the components of Florida's creativity index is tolerance. It is reasonable to assume that tolerant communities will be accepting of and willing to work with various interest groups, including trade unions. People belonging to "working class" or "service class" can move to a "creative class" in the new economy. Along with this, transformation will have changes in the attitude of people towards union as well. Hence, creativity can also be understood as a composite index of structural change in the labor market. Thus, we can hypothesize that higher the level of creativity of a country is, the higher will be the level of union density.

Culture is another neglected variable in the literature pertaining to union density. Various scholars have conceptualized and measured culture in varying contexts (Hall, 1981; Triandis, 1995; Hofstede, 1991). The most widely used measure of culture in empirical studies is the one developed by Hofstede. He has identified four dimensions of national culture-power distance, individualism vs. collectivism, masculinity vs. femininity and uncertainty avoidance. 
Power distance is related to differences between people in their willingness to accept authority. Higher power distance cultures value hierarchy, status, protocols and formality, whereas low power distance cultures value equality and justice. Since unions are perceived as institutions that promote equality, a larger power distance should mean more inequality. Hence, PDI (Power Distance Index) should have a negative effect on union density. In individualistic culture, people take responsibility for them and pursue their own self-interest, whereas in collectivist culture relationship, in-group solidarity and cooperation are the important hallmarks. People coming from a highly individualistic culture are less likely to see the benefits of unionism as unions are the institution of collective voice (Freeman \& Medoff, 1984). Hence, we predicted a negative influence of individualistic culture on union density. Masculine culture is related to assertiveness, independence, task orientation and self-achievement. On the other hand, feminine culture emphasizes cooperation, relationship, modesty and solidarity with others, even the less fortunate ones. Since assertiveness is the predominant characteristic of a masculine culture, we predicted a positive effect of this variable on union density. In cultures high in avoidance of uncertainty, people avoid uncertain and unpredictable situations, whereas in cultures low in uncertainty avoidance, people are more accepting of risk and unpredictability. This cultural dimension will also have implications for trade union density. However, the sign of direction is a priori inconclusive because unions sometimes reduce (through collective agreement) and sometimes increase (through strike and other disruptive practices) at the same time.

To the best of our knowledge, there is only one study to date that used culture to explain variations in union density (Singh, 2001). However, the researcher used only dimensions of culture in the regression model for union density in 33 countries that he estimated during the period of 1985-1995. Needless to say, culture alone will not be sufficient to explain variations in union densities across nations. Hence, it needs to be worked into a more elaborate model of union growth. And that is what we are doing here.

\section{Empirical Evidence}

Based upon the theoretical considerations presented in the last section, we formulated the following general model of trade union density for estimation purpose:

$$
\text { Density }=f \text { (creativity, culture and economy) }
$$

In equation (1), the dependent variable, density, is union density defined as the percentage of non-agricultural workers belonging to a union. Data for trade union density were supplied by the International Labour Office. The explanatory variables are creativity, culture and economy. Our measure of creativity is a composite index of three Ts-tolerance, technology and talent developed by Florida (2002). Dimensions of national culture are the ones developed by Hofstede (1991). There are four dimensions of national culture-power distance, individualism vs. collectivism, masculinity vs. femininity and uncertainty avoidance. In this study, we included three dimensions of culture: power distance, individualism vs. collectivism, masculinity vs. femininity, due to availability of published data for a consistent set of years. Hofstede (1991) is the source of data for these three culture variables. The context of economic environment, economy variable, is proxied by the growth of per capita GDP and unemployment rate. The increases of price and nominal wage are assumed to be embedded in the per capita rate of GDP. Data for the rate of growth of GDP are taken from the World Bank’s World Development Indicators published by the World Bank. Unemployment rate is taken from the Yearbook of Labour Statistics published by the International Labour Office. Union density is defined as the percentage of non-agricultural workers belonging to a union. Data for trade union density were supplied by the 
International Labour Office. Countries included in the study are Australia, Austria, Belgium, Canada, Czech Republic, Denmark, Finland, France, Germany, Greece, Iceland, Ireland, Japan, Netherlands, New Zealand, Norway, South Korea, Spain, Sweden, Switzerland, UK and USA.

For estimation purpose, variables entering equation (1) were transformed into their natural logarithms and first differences and rewritten in their linear form as follows:

$(\ln )$ Density $=a_{0}+b_{1}(\ln )$ Creativity $+b_{2}(\ln )$ Power distance $+b_{3}(\ln )$ Individualism

$+b_{4}(\ln )$ Masculinity $+b_{5}(\ln )$ GDP per capita growth

$+b_{6}(\ln )$ Unemployment rate $+e$

In equation (2), $\ln$ is natural logarithms; $a_{0}$ is the constant term, $b_{1}$ to $b_{6}$ are coefficients to be estimated, and $e$ is the random error term. In our estimation phase, we hypothesized that past union density could also affect current union density. To capture the effect of the past union density, we included the lagged dependent variable (lagged one year) as an additional explanatory variable.

Prior to our estimation, we analyzed the raw data in their natural logarithms by looking at the descriptive statistics. Table 1 presents the descriptive statistics of all variables used in the estimation phase. It presents the values of the means, standard deviation, variance and minimum and maximum scores for the dependent and independent variables. The results presented in Table 1 are self-explanatory and does not need further emphasis in terms of their interpretation.

Table 1

Descriptive Statistics

\begin{tabular}{lrllcc}
\hline Variables & Mean & Standard deviation & Variance & Minimum & Maximum \\
\hline (Log) Union density & 3.36 & 0.621 & 0.386 & 2.116 & 4.375 \\
(Log) Creativity & -0.63 & 0.229 & 0.052 & -1.008 & -0.213 \\
(Log) Power distance & 3.62 & 0.453 & 0.205 & 2.398 & 4.219 \\
(Log) Individualism & 4.15 & 0.370 & 0.137 & 2.890 & 4.511 \\
(Log) Masculinity & 3.70 & 0.783 & 0.614 & 1.609 & 4.554 \\
(Log) GDP per capita growth & 0.83 & 0.418 & 0.175 & -0.048 & 1.798 \\
(Log) Unemployment rate & 1.84 & 0.394 & 0.152 & 1.264 & 2.668 \\
\hline
\end{tabular}

Note. Source: Authors computations based on data described above.

Our estimation begins with the regression analysis of equation (2) using the method of OLS (Ordinary Least Squares) with all variables transformed into their natural logarithms and in first difference. The estimated results are reported in Table 2 where the numerical results include estimated coefficients, $t$-statistics in parentheses, the $F$-statistics and the goodness of fit measured by $R$-square. A unique feature of Table 2 is that we report the results of equation (2) estimated in several different specifications. The far left hand column of Table 2 lists the explanatory variables as described in equation (2) including the lagged dependent variable (lagged union density) to capture the effect of past union density. The far left hand side column also includes the $F$-statistics and fit of the model based on the $R$-square. The $F$-statistics is statistically significant. The fit of the model ranges from 0.82 to 0.86 across the several specifications tested and is considered to be highly satisfactory for models estimated in the first differences of their natural logarithms. The specifications 1 to 5 in Table 2 indicate that equation (2) is tested in five different forms. Our intentions in testing several forms of equation (2) are to gauge the relative effects of the three core variables: creativity, culture and economy on union density and measure their importance separately as well as in a combined manner. For example, specification 1 attempts to capture the effect of past union density and creativity on union density alone, while 
Specification 2 captures the effect of culture variables with past union density on union density; Specification 3 reports the results of all culture variables together with past union density and creativity on union density; Specification 4 reports the effect of economy variables with past union density, but without the culture variables to probe if economic environment matters for union density; and Specification 5 reports the results of all variables combined on union density.

Table 2

Regression Results of Trade Union Density With Lagged Dependent Variable

\begin{tabular}{|c|c|c|c|c|c|}
\hline Variables & Specification 1 & Specification 2 & Specification 3 & Specification 4 & Specification 5 \\
\hline Constant & $\begin{array}{c}3.319 \\
(4.935)^{*}\end{array}$ & $\begin{array}{c}3.514 \\
(4.616)^{*}\end{array}$ & $\begin{array}{c}2.722 \\
(2.985)^{*}\end{array}$ & $\begin{array}{c}3.309 \\
(5.958)^{*}\end{array}$ & $\begin{array}{c}2.872 \\
(3.090)^{*}\end{array}$ \\
\hline Lagged union density & $\begin{array}{l}-1.059 \\
(6.189)^{*}\end{array}$ & $\begin{array}{c}1.048 \\
(4.656)^{*}\end{array}$ & $\begin{array}{l}-0.889 \\
(3.613)^{*}\end{array}$ & $\begin{array}{l}-0.999 \\
(6.173)^{*}\end{array}$ & $\begin{array}{l}-0.915 \\
(3.729)^{*}\end{array}$ \\
\hline Creativity & $\begin{array}{l}-0.485 \\
(1.466)\end{array}$ & $\ldots$ & $\begin{array}{l}-0.628 \\
(1.469)\end{array}$ & $\ldots$ & $\begin{array}{l}-3.934 \\
(0.845)\end{array}$ \\
\hline Power distance & $\ldots$ & $\begin{array}{r}0.079 \\
(0.382)\end{array}$ & $\begin{array}{l}-0.143 \\
(0.566)\end{array}$ & $\ldots$ & $\begin{array}{l}-0.176 \\
(0.681)\end{array}$ \\
\hline Individualism & $\ldots$ & $\begin{array}{r}0.147 \\
(0.629)\end{array}$ & $\begin{array}{r}0.215 \\
(0.934)\end{array}$ & $\ldots$ & $\begin{array}{c}0.052 \\
(0.200)\end{array}$ \\
\hline Masculinity & $\ldots$ & $\begin{array}{l}-0.209 \\
(1.352)\end{array}$ & $\begin{array}{l}-0.168 \\
(1.108)\end{array}$ & $\ldots$ & $\begin{array}{l}-0.016 \\
(0.085)\end{array}$ \\
\hline GDP per capita growth & $\ldots$ & $\ldots$ & $\ldots$ & $\begin{array}{c}0.444 \\
(2.285)^{* *}\end{array}$ & $\begin{array}{c}0.346 \\
(1.125)\end{array}$ \\
\hline Unemployment rate & $\ldots$ & $\ldots$ & $\ldots$ & $\begin{array}{r}0.246 \\
(1.025)\end{array}$ & $\begin{array}{c}0.287 \\
(0.872)\end{array}$ \\
\hline$F$-statistics & 40.0 & 17.9 & 15.8 & 33.2 & 11.7 \\
\hline$R$-square & 0.82 & 0.82 & 0.84 & 0.85 & 0.86 \\
\hline
\end{tabular}

Notes: "indicates statistically significant at the level of $1 \% ;{ }^{* *}$ indicates statistically significant at the level 5 of $\% ; \ldots$ indicates variable not estimated.

In Table 2, we begin our discussion of the general equation (2) based on the results of Specification 1 which tests the effect of past union density and creativity on union density. The coefficient, lagged union density is negative and statistically significant at the level of $1 \%$, indicating inverse effect of past union density on current union density. The coefficient, creativity, is negative and statistically insignificant. In Specification 2, we test the effect of lagged union density with culture variables (power distance, individuality and masculinity). Lagged union density has a positive and statistically significant effect on the union density, while the coefficients of power distance and individuality are positive, but statistically insignificant. Variable masculinity has a negative coefficient and is statistically insignificant. Specification 3 tests the effect of culture variables with creativity and lagged dependent variable. Among the culture variables, power distance and masculinity are negative and statistically insignificant, while creativity has a negative coefficient and statistically insignificant. The lagged dependent variable has a negative coefficient and is statistically significant at the level of $1 \%$. Specification 4 tests the effect of economy variables (per capita GDP growth and unemployment rate) together with lagged dependent variable. Our results indicated a positive and statistically significant effect of per capita GDP growth on union density and positive but statistically insignificant effect of unemployment rate on union density. Specification 5 tests the complete model, including all variables. The lagged dependent variable is negative and statistically significant at the level of $1 \%$, while creativity is negative but statistically insignificant. Among the culture variables, power distance has negative and statistically insignificant coefficients, while individualism is positive but statistically insignificant. While the coefficients of the two economy variables are 
positive, they are statistically insignificant.

Our results in Table 2 consistently indicate a negative and statistically significant effect of lagged dependent variable (past union density), which is contrary to our theoretical expectations. As such we dropped the measure of past union density (lagged dependent variable) from all of our specifications and re-estimated specifications 1 to 5 . Our results improve and gain more strength (see Table 3).

Table 3

Regression Results of Trade Union Density Without Lagged Dependent Variable

\begin{tabular}{|c|c|c|c|c|c|}
\hline Variables & Specification 1 & Specification 2 & Specification 3 & Specification 4 & Specification 5 \\
\hline Constant & $\begin{array}{l}-0.691 \\
(2.223)^{* * *}\end{array}$ & $\begin{array}{c}0.028 \\
(0.139)\end{array}$ & $\begin{array}{l}-0.528 \\
(1.890)^{* * *}\end{array}$ & $\begin{array}{l}-0.039 \\
(0.184)\end{array}$ & $\begin{array}{l}-0.499 \\
(1.675)\end{array}$ \\
\hline Creativity & $\begin{array}{c}-17.133 \\
(3.735)^{*}\end{array}$ & $\ldots$ & $\begin{array}{c}-13.269 \\
(2.598)^{*}\end{array}$ & $\ldots$ & $\begin{array}{l}-11.900 \\
(2.074)^{* *}\end{array}$ \\
\hline Power distance & $\ldots$ & $\begin{array}{r}0.066 \\
(0.212)\end{array}$ & $\begin{array}{l}-0.400 \\
(1.237)\end{array}$ & $\ldots$ & $\begin{array}{l}-0.461 \\
(1.343)\end{array}$ \\
\hline Individualism & $\ldots$ & $\begin{array}{c}0.890 \\
(3.511)^{*}\end{array}$ & $\begin{array}{c}0.796 \\
(3.585)^{*}\end{array}$ & $\ldots$ & $\begin{array}{c}0.635 \\
(2.226)^{* *}\end{array}$ \\
\hline Masculinity & $\ldots$ & $\begin{array}{l}-0.430 \\
(1.963)^{* * *}\end{array}$ & $\begin{array}{l}-0.273 \\
(1.376)\end{array}$ & $\ldots$ & $\begin{array}{l}-0.163 \\
(0.649)\end{array}$ \\
\hline GDP per capita growth & $\ldots$ & $\ldots$ & $\ldots$ & $\begin{array}{c}0.711 \\
(2.140)^{* *}\end{array}$ & $\begin{array}{r}0.110 \\
(0.489)\end{array}$ \\
\hline Unemployment rate & $\ldots$ & $\ldots$ & $\ldots$ & $\begin{array}{c}1.076 \\
(3.079)^{*}\end{array}$ & $\begin{array}{r}0.392 \\
(0.862)\end{array}$ \\
\hline F-statistics & 14.1 & 7.5 & 9.3 & 10.1 & 5.9 \\
\hline$R$-square & 0.43 & 0.57 & 0.70 & 0.53 & 0.72 \\
\hline
\end{tabular}

Notes: ${ }^{*}$ indicates statistically significant at the level of $1 \% ;{ }^{* *}$ indicates statistically significant at the level of $5 \%$; ${ }^{* * *}$ indicates statistically significant at the level of $10 \% ; . .$. indicates variable not estimated.

In Table 3, our findings of the creativity variable consistently reveal a negative coefficient across the specifications tested (Specifications 1, 3 and 5). The coefficient creativity is also statistically significant at the level of $1 \%$ in all cases.

In terms of the effect of culture variables, our findings in Table 3 indicate that among the three measures of culture adopted here, individualism is positive and statistically significant at the level of $5 \%$ (Specification 5) and level of 1\% (Specifications 2 and 3). Our finding of individualism leads to the suggestion that variable is strongly and positively associated with union density. As individualism increases, union density also increases. Masculinity is another culture variable tested with a negative and statistically significant effect (Specification 2), but negative and insignificant effect in Specification 3 and also when the complete model was tested (Specification 5). The culture and creativity related variables kept their significant levels as well as the signs of direction as predicted in the theoretical discussion in the previous section. The signs of the cultural dimension variables as well as their estimated coefficients are in line with those obtained by Singh (2001). Almost half of the variations (49\%) in union density across sample countries are explained by this model.

In terms of our economy variable, Table 3 reports positive coefficients-the two economy variables: per capita GDP growth and unemployment rate. While the coefficients are insignificant when the complete model was tested (Specification 5), both variables produced a statistically significant coefficients when tested on a standalone basis (Specification 4). The findings of the positive and statistically significant effect in Specification 4 provide strong confirmation that economy variables are important determinants of union density. As economic growth improves and union density rises, and when unemployment levels increase, union density 
also increases. These findings of the economy variables do have major policy implications as far as union density is concerned and in general labor market outcomes when economic conditions improve or deteriorate.

\section{Conclusions and Policy Implications}

This paper has made an important contribution to trade union membership growth literature as it has incorporated three major theoretical dimensions: culture, creativity and economy variables into the trade union growth model. The findings of the research presented here augment the cross-national institutional theories of temporal differences in union density rates across countries. This line of research is certainly needed, because the economy has departed from the old model even though the literature on trade union membership growth still continues to use explanatory variables characteristics of the old economic model. This is one of the motivations for carrying out this empirical study.

Our findings have implications for trade unions as institutions determining labor market outcomes and wider socio-political effects. One of the key implications is that the union density is unlikely to reverse in the immediate future, as the knowledge-based economy begins to take a firmer hold because the foundation of such an economy is creativity and this variable is found to have a negative effect on union density as revealed in this study. Also, it is important to understand that one of the elements of creativity is tolerance. Since more tolerant societies are more willing to accept role of interest groups, there may be more public support coming for trade unions in future. That is to say, as the knowledge economy evolves further, the density decline may change its course in the long run. Individualism also plays an important determining role where freedom to express oneself and having the liberty to join interest groups based on one's own conscience adds further support to the existence of trade unions. Our study provides strong evidence that individualism has an important role in terms of union density and is a strong determinant. It is positively and statistically significantly associated with union density as revealed in this study. Our findings also provide evidence that labor market conditions also determine union density. In particular, rising unemployment is associated with union density despite of the fact that its sign is found to be contrary to theoretical expectations. In addition, economic environment also matters for trade union density. Our findings provide strong empirical evidence that as economic growth improves, trade union density increases because more workers are likely to be in a better job situation to join unions. Economic growth may also have spill-over effects in terms of rising worker expectations and incomes. The credit effect discussed earlier may lead to further growth of union membership, and hence, density.

However, the study has some limitations as well. First, due to data limitations for both creativity and cultural factors, the sample size has been rather small. Secondly, the study has used trade union density data for the year of 2005. This point-in-time data is a problem because such data cannot capture sensitive developments influencing the pattern of density decline or growth over a longer period of time. Average over a decade or so instead of data for a year would have taken care of this problem. Further research to rectify these problems is necessary for generalizations of the findings. Additional research involving comparative data for both developed and developing countries would shed more light to this line of research, as developing countries are host to large numbers of labor force and their rapidly changing economic environment characterized by phenomenal growths in some of the large developing economies would certainly add value to this line of research. The authors are pursuing this line of additional research. 


\section{References}

Bain, G. S., \& Elsheikh, F. (1976). Union growth and the business cycle. Oxford: Blackwell.

Bhattacherjee, Debashish, \& Chaudhuri, Tamal Datta. (1994). Modeling trade union growth in India. The Indian Journal of Labour Economics, 37(1), 67-72.

Booth, A. (1985). The free rider problem and a social custom theory of trade union membership. Quarterly Journal of Economics, 100, 253-261.

Booth, A., \& Chatterji, M. (1995). Union membership and wage bargaining when membership is not compulsory. Economic Journal, 105, 345-360.

Checchi, D., \& Visser, J. (2005). Pattern persistence in European trade union density. European Sociological Review, 21(1), 1-21.

Elsheikh, F., \& Bain, G. S. (1978). American trade union growth: An alternative model. Industrial Relations, 17, 75-79.

Fiorito, J. (1982). American trade union growth: An alternative model. Industrial Relations, 21, 123-127.

Florida, R. (2002). The rise of the creative class and how it's transforming work, leisure, community, and everyday life. Melbourne: Pluto Press Australia.

Freeman, R., \& Medoff, J. L. (1984). What do unions do? New York: Basic Books.

Hall, E. T. (1981). Beyond culture. New York: Basic Books.

Hofstede. G. (1991). Culture and organizations. London: Harper Collins.

International Labour Organization. (2008). Yearbook of labour statistics. Geneva: ILO.

Johnson, S. (2002). Canadian union density 1980 to 1998 and prospects for the future: An empirical investigation. Canadian Public Policy, 28(3), 333-349.

Kumar, P., \& Dow, B. (1986). Econometric analysis of union membership growth in Canada. Relations Industrielles, 41, $236-255$.

Rose, J., \& Chaison. G. (1996). Linking union density and union effectiveness: The North American experience. Industrial Relations, 35(1), 78-105.

Sharma, B. (1989). Korean trade union growth during the period 1962-1984. Economics Letters, 31, 105-108.

Singh, G. (2001). National culture and union density. Journal of Industrial Relations, 43(3), 330-339.

Triandis, H. C. (1995). Individualism and collectivism. Boulder, C. O.: Westview.

United Nations. (2008). Yearbook of national income statistics. New York: United Nations.

Vandaele, K. (2005). A half century of trade union membership: The cyclical macro-determinants of postwar union growth in Belgium. World Political Science Review, 1(2), 53-72. Retrieved from http://www.bepress.com/wpsr/vol1/iss2/art3

Visser, J. (2002). Why fewer workers join unions in Europe: A social custom explanation of membership trends. British Journal of Industrial Relations, 40(3), 403-430. 